\title{
COMPOSITIONAL FIBERS BASED ON COAL TAR MESOPHASE PITCH OBTAINED BY ELECTROSPINNING METHOD
}

\author{
Aldan Imangazy ${ }^{1,}$, ,Gaukhar Smagulova1, 2, Bayan Kaidar ${ }^{1,2}$, \\ Zulkhair Mansurov1,2, Almagul Kerimkulova', 2, Kuanysh Umbetkaliev', \\ Anvar Zakhidov ${ }^{3}$, Pavel Vorobyev ${ }^{4}$, Talkybek Jumadilov ${ }^{4}$
}

https://doi.org/10.23939/chcht15.03.403

\begin{abstract}
This research examines the use of coalprocessing wastes of Shubarkol deposit (Kazakhstan) in obtaining useful materials such as carbon fibers. For our experiments, mesophase pitch was obtained by coal tar heat treatment at $773 \mathrm{~K}$. Spinnable solution was prepared by crushing mesophase pitch into the pieces with adding poly(methylmethacrylate) as a fiber-forming material and 1,2-dichloroethane as a solvent. Elemental analysis revealed that the chemical composition of mesophase pitch $(\mathrm{C}-91.48 \%$; O $-8.52 \% ; \mathrm{S}-0.00 \%)$ showed that heat treatment up to $773 \mathrm{~K}$ leads to the complete removal of sulfur-containing components which affect the mesophase formation. Raman data of the obtained pitch revealed the appearance of $\mathrm{D}\left(1366 \mathrm{~cm}^{-1}\right)$ and $\mathrm{G}\left(1605 \mathrm{~cm}^{-1}\right)$ peaks, which are responsible for carbon materials; another peak at $2900 \mathrm{~cm}^{-1}$ shows the presence of $\mathrm{C}-\mathrm{H}$ bonds. Carbon fibers with the diameter of $0.8-1.75 \mu \mathrm{m}$ were obtained by electrospinning method in laboratory settings.
\end{abstract}

Keywords: coal tar, mesophase pitch, electrospinning, carbon fiber.

\section{Introduction}

Coal is one of the important exponents of fossil raw material and does not lose its value for many years. Coal coke is a product of coal pyrolysis, which has found its application in industry, in the production of steel and

\footnotetext{
${ }^{1}$ Kazakh National University named after al-Farabi,

71 al-Farabi Ave., Almaty 050040, Republic of Kazakhstan

${ }^{2}$ Institute of Combustion Problems,

172 Bogenbaybatyr St., Almaty 050012, Republic of Kazakhstan

${ }^{3}$ University of Texas at Dallas,

800 W. Campbell Road, Richardson 75080-3021, Texas, USA

${ }^{4}$ Bekturov Institute of Chemical Sciences,

106 Sh. Ualikhanov St., Almaty 050010, Republic of Kazakhstan

imangazy.aldan@mail.ru

(c) Imangazy A., Smagulova G., Kaidar B., Mansurov Z.,

Kerimkulova A., Umbetkaliev K., Zakhidov A., Vorobyev P., Jumadilov T., 2021
}

cast iron, in the chemical industry for its excellent adsorption performance, processability, etc. During coal coking process, coal gas, aromatics mixture, ammonia water and coal tar are extracted. Coal tar pitch is a possible precursor for carbon fiber production [1-3].

Coal tar is always formed during the production of coke, which is essential for metallurgy. For example, «ShubarkolKomir» JSC (Kazakhstan) alone produces up to 35.000 tons of coal tar annually as by-product [4]. Being a thick black liquid with a specific odor, coal tar is a complex mixture of aromatic hydrocarbons, heterocyclic sulfur-, oxygen- and nitrogen-containing compounds. By further coal tar processing, valuable products such as benzene, toluene, xylenes, etc., as well as sleeper impregnation oil, plastics, pitched-based electrodes, binding pitch, carbon fibers, etc. might be produced [5].

According to the British Petroleum Statistical Review 2020, in terms of proven coal reserves, Kazakhstan ranked as $10^{\text {th }}$ in the world ( $2.4 \%$ of global reserves) and the $9^{\text {th }}$ among countries in terms of coal output $(2.08 \%$ of world production) [6]. The production of this huge amount of coal requires the development of a waste-free technology based on its deep processing. Spinnable mesophase pitch could be converted into target products with high economic demand such as carbon fibers. The production of carbon fibers finds a wide application in medicine, biotechnology, energy, in treatment facilities, and in construction to obtain composite materials, aerospace, etc. [7].

One of the intermediate products of coal processing is coal tar. A product of coal tar processing is pitch. The two basic types of pitch are anisotropic (mesophase) and isotropic (non-mesophase). There are two commonly used methods of converting isotropic pitch into mesophase pitch. The first method is the production of mesophase by pyrolysis and the second is the production of mesophase pitch by solvent treatment. Manufacture of mesophase by pyrolysis involves heating it under an inert gas such as nitrogen for approximately $40 \mathrm{~h}$. The optically isotropic material is transformed into an optically anisotropic liquid stage mesophase by the heat treatment [8]. 
The main disadvantage of coal tar pitch is its high carcinogenic activity because of the specificity of its chemical composition with high content of polycyclic aromatic hydrocarbons and phenols. Three types of polyaromatic hydrocarbons are classified as extremely hazardous: benz(a)anthracene, benz(a)pyrene and dibenz(a,h)anthracene. Benzo(a)pyrene is an indicator of carcinogenic hazard, the concentration of which in the air should not exceed $9 \mathrm{~g} / \mathrm{m}^{3}$ [9]. Therefore, by contacting with coal tar, the rules for working with hazardous substances should be observed, avoiding exceeding the maximum permissible concentration of coal tar sintering products in the air under laboratory conditions.

On an industrial scale, coal tar could be processed into three product groups: 1) aromatic hydrocarbons such as naphthalene, xylenols, individual cresols, phenols; 2) various lubricants, coatings, and technical oils; 3) raw materials for the production of carbon-graphite materials such as coal tar pitch and pitch coke.

Carbon fibers are promising materials that outperform other materials in their unique characteristics such as high chemical resistance, high tensile strength, light weight, and low coefficient of thermal expansion $[10,11]$. These fibers could be obtained by electrospinning method. The technique of electrospinning is a complex physicochemical process that depends on many factors and, primarily, on the choice of the precursor and its preparation $[12,13]$. Polymers are the most widely used fiber-forming materials. In our research we used poly(methylmethacrylate) as a fiber-forming material as common and available polymer. The main goal of this work was to obtain fibers from coal-processing wastes such as coal tar using electrospinning method [14].

In our previous work [15], we obtained carbon fibers by the electrospinning method with the diameter of 2-9 $\mu \mathrm{m}$. To obtain mesophase pitch, coal tar was heated up to $673 \mathrm{~K}$ with heating rate of $15 \mathrm{~K} / \mathrm{min}$ in argon atmosphere. Studies have shown that the processing of coal tar makes it possible to obtain unique materials with the prospect of obtaining materials of the nanoscale range.

The physic-chemical characteristics of the feedstock and the temperature regime of its processing affect the occurrence of mesophase changes. The quality of the pitch is determined by the presence of sulfurcontaining components and insoluble residues [16].

In this research, carbon fibers were produced with the thinner diameters of $0.8-1.75 \mu \mathrm{m}$ by electrospinning method. The transition of carbon pitch into the mesophase structure occurs through the formation of an intermediate isotropic-mesophase structure under the influence of temperature. Coal tar heat treatment up to $773 \mathrm{~K}$ led to the complete removal of sulfur content in mesophase pitch.
The process of the mesophase formation is influenced by the initial composition of the original pitch and also by the presence of heteroatoms in the pitch content. The heteroatoms in the molecule of the resulting pitch affect the formation of the mesophase itself. An increase in the content of oxygen and sulfur in obtained pitch affects the graphitability of the system, which sharply decreases, for example, with a sulfur content of 5-9\%, the formed carbon does not form a graphite structure. This effect of sulfur is explained by the occurrence of reactions of dehydrogenation and crosslinking of layers of macromolecules in crystallites and, as a result, by a decrease in their mobility [17].

One of the methods for producing fibers is spinning them from polymer solutions. Electrospinning is a process that leads to the formation of fibers under the action of electrostatic forces on an electrically charged solution flow $[18,19]$. This method consists in the fact that an electric voltage is applied to the solution passing through the capillary of the dosing device in the range from 1 to $100 \mathrm{~kW}$ [14]. Such high voltage values induce similar electric charges in the solution, leading to the pulling of the solution into a thin flow due to the Coulomb electrostatic interaction $[20,21]$. Due to the evaporation of the solvent, the filaments of the solution harden under the action of electrostatic forces and turn into fibers with a transition to a grounded substrate (collector) having the opposite electric potential. The fiber collector should have an excellent electrical conductivity [15].

Carbon fibers are an extremely important carbon material, which are mostly used for the production of composite, heat-shielding, chemically resistant and other types of carbon fiber reinforced plastics. Fibers based on poly(acrylonitrile) are relatively expensive. The solution to the problem is to develop a technology for the production of mesophase pitch as a raw material for the production of high-modulus, high-strength carbon fibers based on cheap raw material as coal tar for producing carbon fibers with high physical and mechanical properties.

\section{Experimental}

\subsection{Materials}

Coal tar formed during the coking of Shubarkol deposit coals (Kazakhstan) was used. Some characteristics of coal tar: viscosity at $353 \mathrm{~K}$ is 3.0 conventional degrees, density at $293 \mathrm{~K}$ is $1060 \mathrm{~kg} / \mathrm{m}^{3}$, coking capacity is 2.0 $3.5 \%$; flash point is $388 \mathrm{~K}$; softening temperature is $338 \mathrm{~K}$; volatile matter is $83.0 \%$. As a solvent, we used 1,2-dichloroethane (Sigma-Aldrich, Germany). Poly(methyl 
methacrylate) (Sigma-Aldrich, Germany) was used as a binder.

\subsection{Methods of Analysis}

To determine the surface structure and morphology of the obtained carbon fibers we used Quanta 200i 3D scanning electron microscope (FEI Company, USA); accelerating voltage $30 \mathrm{kV}$ (provided by the National Nanotechnology Laboratory at the al-Farabi Kazakh National University). For registration of Raman spectra, we used an Integra Spectra probe-scanning microscope by a laser with a wavelength of $473 \mathrm{~nm}$. The sample was supported as a thin replica on a glass substrate. The CCD3 spectral detector had the wavelength of $632.8 \mathrm{~nm}(20 \mathrm{mV})$ with the spectral line width of $2.08 \mathrm{~cm}^{-1}$. Device parameters: power $35 \mathrm{~mW}$, solid-state laser, grating $600 / 600$ (provided by the National Nanotechnology Laboratory at the al-Farabi Kazakh National University).

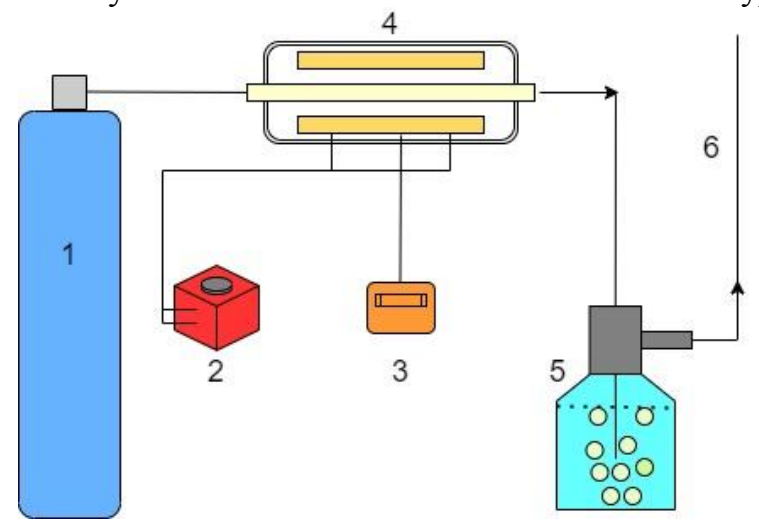

Fig. 1. Schematic diagram of laboratory installation for coal tar pitch obtaining: 1 - gas cylinder (argon); 2 - laboratory autotransformer; 3 - thermostat; 4 - quartz reactor; 5 - gas outlet flask controller; 6 - gas outlet

\subsection{Preparation of Mesophase Pitch}

Mesophase pitch was obtained by coal tar heat treatment at $773 \mathrm{~K}$ with a heating rate of $15 \mathrm{~K} / \mathrm{min}$ by holding at $773 \mathrm{~K}$ for $3 \mathrm{~h}$ in an argon medium. Argon consumption was $80 \mathrm{~cm}^{3} / \mathrm{min}$. The initial coal tar was placed in dried and weighed porcelain "boat" (Fig. 2a).

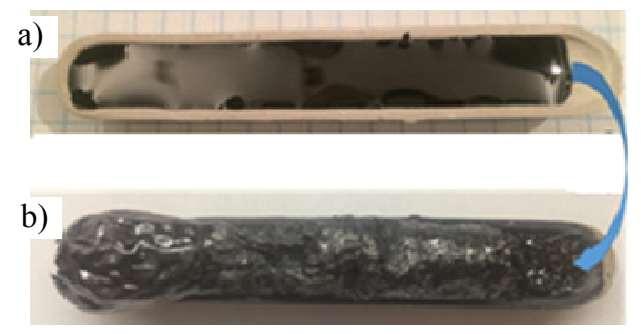

Fig. 2. Initial coal tar (a) and after heat treatment at $773 \mathrm{~K}(\mathrm{~b})$
The heat treatment was conducted in a quartz reactor (Fig. 1) with the diameter of $30 \mathrm{~mm}$. Then the reactor was cooled and coal tar pitch was removed. After removal from the reactor, the "boat" was weighed to determine the mass loss of the final product (Fig. 2b).

Heat treatment of the original coal tar turned it from a viscous state to a solid one, and the final product increased in volume. Removal of low-boiling fractions in the form of vapours led to the formation of mesophase pitch with a porous structure as a friable spongy material.

\subsection{Preparation of Carbon Fibers}

The electrospinning method as a complex physicchemical process depends on many factors and, largely, on the choice of the precursor and its preparation. Polymers are widely used fiber-forming materials. In our research we used poly(methyl methacrylate) as a binder.

The technological scheme of carbon fibers production from coal tar consists of the following stages: preparation of raw materials at $773 \mathrm{~K}$; dissolving of pitch and poly(methyl methacrylate) in 1,2-dichloroethane; electrospinning process; stabilization of the obtained fibers in an oxygen atmosphere, carbonization in an inert atmosphere.

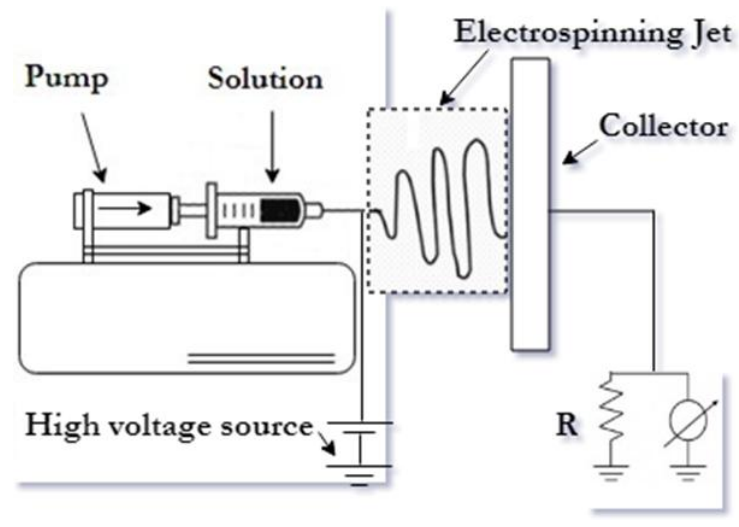

Fig. 3. Scheme of electrospinning installation

For the process of electrospinning, the obtained pitch was crushed and 1,2-dichloroethane was added. For uniforming, the resulting mixture was placed for $25 \mathrm{~min}$ in an ultrasonic bath. Poly(methyl methacrylate) as a binder was also mixed with 1,2-dichloroethane and put in an ultrasonic bath for $25 \mathrm{~min}$. Their common mixture in 1:1 ratio was placed in an ultrasonic bath for $35 \mathrm{~min}$.

Electrospinning (Fig. 3) occurs when the electric field between the electrodes and the electrostatic forces between the charges accumulated in the spinning solution overcome the surface tension of the solution. The action of the repulsive force between the same charges stretches the viscoelastic flow of the molding solution. Fig. 6 shows the obtained fibers with the diameter of $0.8-1.75 \mu \mathrm{m}$, 
where the structural elements take the form of filamentary formations.

\section{Results and Discussion}

A sample of coal tar before and after the heat treatment process was weighed to determine the posttreatment mass loss. It was found that the weight loss during heat treatment at $773 \mathrm{~K}$ was $70 \%$ of the original weight. This is because heat treatment leads to the removal of volatile fractions from coal tar.

The results of the elemental analysis showed the elemental composition of obtained coal tar pitch composed by weight percentage: $\mathrm{C}-91.48 \%, \mathrm{O}-$ $8.52 \%$. In our previous research [15], coal tar was heated up to $673 \mathrm{~K}$ and the elemental analysis showed a sulfur content of $0.73 \%$ in the coal tar pitch, whereas the heat treatment of the coal tar to $773 \mathrm{~K}$ results in complete sulfur removal. Fig. 4 shows the optical microscopy image of coal tar pitch after the heat treatment at $773 \mathrm{~K}$.

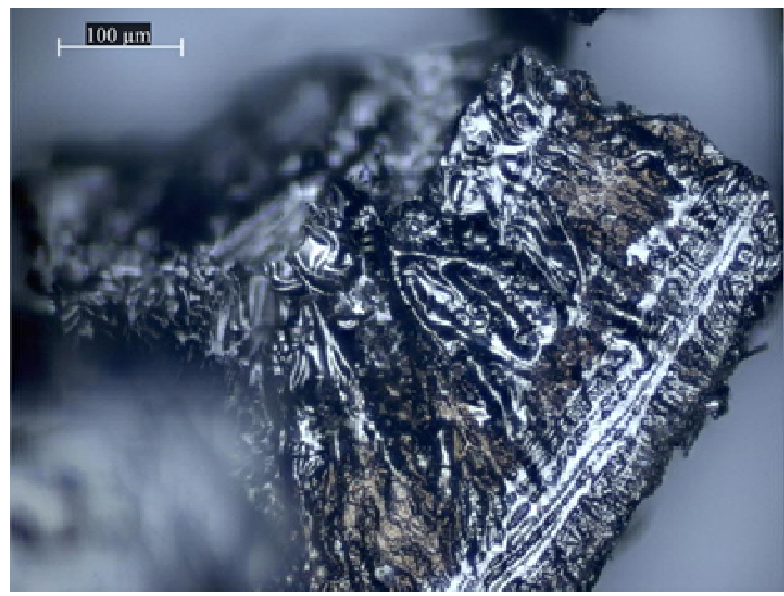

Fig. 4. Coal tar pitch after heat treatment at $773 \mathrm{~K}$

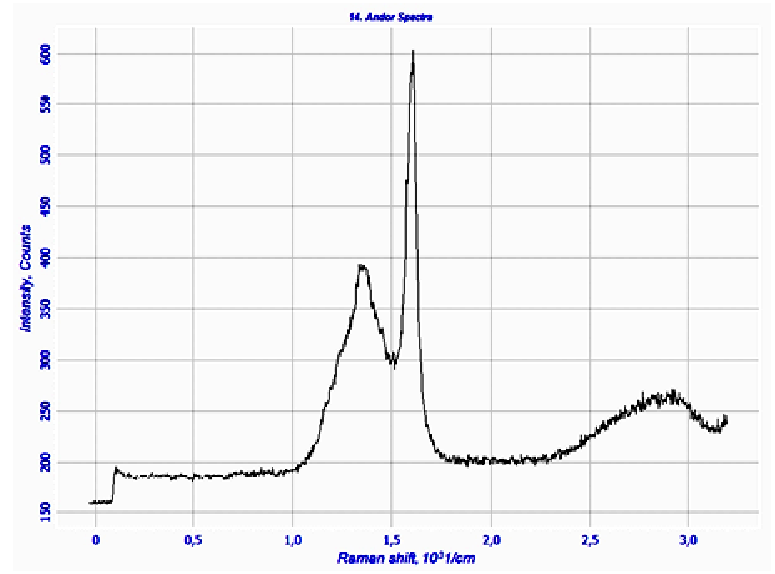

Fig. 5. Raman spectrum of coal tar pitch
The process of mesophase formation depends not only on the initial pitch composition, but also on the presence of heteroatoms in pitch molecules. An increase in the content of oxygen- and sulfur-containing compounds in pitch reduces the graphitability of the system and the resulting carbon does not form a graphite structure. This effect of the sulfur-containing component is explained [16] by the occurrence of dehydrogenation and cross-linking of macromolecule layers in crystallites and, as a result, by a decrease in their mobility.

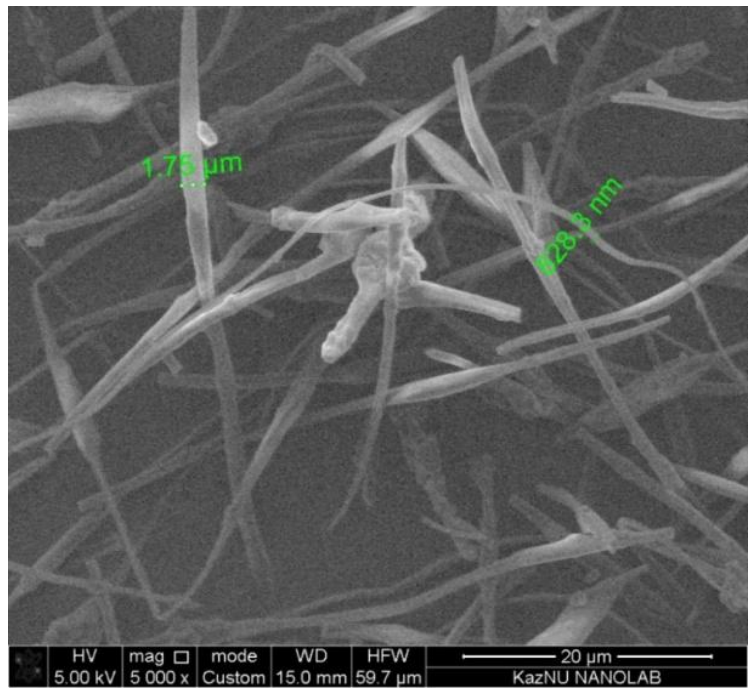

Fig. 6. Electron microscopic images of carbon fibers

Raman spectroscopy analysis was carried out under excitation by unpolarized radiation of a semiconductor diode laser at the wavelength of $\lambda_{e x c}=473 \mathrm{~nm}$. Fig. 5 shows a Raman spectrum, which makes it possible to evaluate the effect of heat treatment on the degree of graphitization of the initial coal tar, where the peaks $\mathrm{D}$ and $G$ characterize the carbon materials [22]. The peak position of $\mathrm{G}\left(1605 \mathrm{~cm}^{-1}\right)$ with the $I_{G}$ intensity of 605 units indicates the formation of nanocrystalline mesophase centers; the D peak at $1366 \mathrm{~cm}^{-1}$ with the $I_{D}$ intensity of 393. The intensity of $G$ is higher than $D$ indicating less disorder due to defects. The peak at $2900 \mathrm{~cm}^{-1}$ shows the presence of $\mathrm{CH}-$ bonds specifying the inclusion of polymers in the pitch composition.

SEM image analysis of carbon fibers (Fig. 6) obtained from coal tar pitch showed that the diameters of the obtained carbon fibers were $0.8-1.75 \mu \mathrm{m}$.

The resulting fibers were subjected to oxidation in the air stream at $573 \mathrm{~K}$ for $1 \mathrm{~h}$ to improve their strength characteristics. The carbonization of the obtained fibers was carried out in a nitrogen atmosphere. The carbonized fibers were then graphitized under tension by passing the electric current through them while electrical heating occurred. 
The interest in carbon fibers production is caused by the fact that the mechanical properties of these materials, such as tensile strength, bending and compression, and elastic moduli increase with decreasing fiber diameter and achieve a theoretical limit when reaching the nanoscale level [23].

\section{Conclusions}

Our research confirms the possibility of using coalprocessing wastes of Shubarkol deposit (Kazakhstan) for production of useful materials with high added value such as carbon fibers. Using electrospinning method, in laboratory settings, we obtained carbon fibers with the diameters of $0.8-1.75 \mu \mathrm{m}$.

The electrospinning method does not need high process chemistry specifications and high filamentsolidification temperatures, and thus enables the production of fibers from elongated and complex molecules. This method allows us to develop a new technology for processing large reserves of coal, particularly, in Kazakhstan, into high-technological products. This technique is a complex, profitable and simple method for carbon fiber production. It makes it possible to obtain valuable materials from coal processing wastes. By processing Shubarkol's coals into pitch, it would be possible to obtain useful materials for further application in the production of carbon fibers outside the laboratory conditions. For industrial scale applications, further process improvements are required.

\section{Acknowledgments}

We would like to thank Renata Nemkayeva from the National Nanotechnology Laboratory at the al-Farabi Kazakh National University (Almaty, Kazakhstan) for the provided microscopic and spectroscopic analysis of the carbon containing materials obtained in this research.

\section{References}

[1] Choi B., Ko J., Park S., Seo M.: Carbon Lett., 2017, 22, 96. https://doi.org/10.5714/CL.2017.22.096

[2] Kim B., Kil H., Watanabe N. et al.: Curr. Org. Chem., 2013, 17, 1463. https://doi.org/10.2174/1385272811317130013

[3] Zhu J., Park S., Joh H. et al.: Carbon Lett., 2013, 14, 94.

https://doi.org/10.5714/CL.2013.14.2.094

[4] https://www.erg.kz/ru/news/693

[5] Derbyshire F., Andrews R., Jacques D. et al:: Fuel, 2001, 80,

345. https:/doi.org/10.1016/S0016-2361(00)00099-5

[6] https://www.bp.com/content/dam/bp/business-

sites/en/global/corporate/pdfs/energy-economics/statisticalreview/bp-stats-review-2020-full-report.pdf
[7] Forintos N., Czigány T.: Compos. Part B-Eng., 2019, 162, 331. https://doi.org/10.1016/j.compositesb.2018.10.098

[8] Aldosari S., Khan M., Rahatekar S.: J. Mater. Res. Technol., 2020, 9, 7786. https://doi.org/10.1016/j.jmrt.2020.05.037

[9] Doshlov O., Kondrat'ev V., Ugap'ev A. et al.: Coke Chem., 2015, 58, 32. https://doi.org/10.3103/S1068364X15010020

[10] Frank E., Steudle L., Ingildeev D. et al.: Angew. Chem. Int. Ed., 2014, 53, 5262. https://doi.org/10.1002/anie.201306129

[11] Yang K., Kim B., Yoon S.: Carbon Lett., 2014, 15, 162. https://doi.org/10.5714/CL.2014.15.3.162

[12] Mochida I., Toshima H., Korai Y., Matsumoto T.: J. Mater.

Sci., 1988, 23, 670. https://doi.org/10.1007/BF01174704

[13] Zhiyuan C., He J., Fengwen Z. et al.: J. Serb. Chem. Soc., 2014, 79, 587. https://doi.org/10.2298/jsc130702150z

[14] Yoo M., Ko H., Lim Y., Kim M.: Carbon Lett., 2014, 15, 247. https://doi.org/10.5714/CL.2014.15.4.247

[15] Yermagambet B., Kazankapova M., Nauryzbaeva A. et al.: News of the Academy of Science of the Republik of Kazakhstan, 2019, 4, 436. https://doi.org/10.32014/2019.2518-170X.101

[16] Park S.-J.: Carbon Fibers. Springer, Dordrecht 2015. https://doi.org/10.1007/978-94-017-9478-7

[17] Singer L., Lewis I.: Carbon, 1978, 16, 417.

https://doi.org/10.1016/0008-6223(78)90086-6

[18] Martinez-Flores R., Camporredondo-Saucedo J., Moreno-C H. et al.: Chem. Chem. Technol., 2017, 11, 230.

https://doi.org/10.23939/chcht11.02.230

[19] Luo C., Stoyanov S., Stride E. et al.: Chem. Soc. Rev., 2012, 41, 4708. https://doi.org/10.1039/c2cs35083a

[20] Kim J., Im U., Lee B. et al.: Carbon Lett., 2016, 19, 72. https://doi.org/10.5714/CL.2016.19.072

[21] http://nano.msu.ru/files/master/I/materials/electromolding.pdf [22] http://igkrc.ru/assets/publication/trudy-2014-1-p1 15-134.pdf

[23] Severyuhina A.,SvenskayaYu., Gorin D.: Izvestiya Saratovskogo Universiteta. Novaya seriya. SeriyaFizika, 2013, 13, 67.

Received: October 19, 2020 / October 22, 2020 / Accepted: December 26, 2020

\section{КОМПОЗИЦЙНІ ВОЛОКНА НА ОСНОВІ МЕЗОФАЗНОГО ПЕКУ КАМ'ЯНОВУГІЛЬНОЇ СМОЛИ, ОТРИМАНИХ МЕТОДОМ ЕЛЕКТРОСПІНІНГУ}

Анотація. Досліджено можливість використання відходів перероблення вугілля родовища Шубарколь (Казахстан) для отримання таких корисних матеріалів, як вуглечеві волокна. Термічним обробленням кам'яновугільної смоли за 773 К одержано мезофазний пек. Приготовлено спініговий розчин подрібненням мезофазного пеку з додаванням полі(метилметакрилату) як волокноутворюючого матеріалу та 1,2дихлоретану як розчинника. За допомогою елементного аналізу підтверджено, щчо термооброблення за 773 К приводить до повного видалення сірковмісних компонентів, які впливають на утворення мезофази (хімічний склад мезофазного пеку C $91,48 \% ; O-8,52 \% ; S-0,00 \%$ ). Присутність вуглечевих матеріалів і зв'язків $C-H$ підтверджено даними раманівської спектроскопії (пікі $D\left(1366 \mathrm{~cm}^{-1}\right)$ та $G\left(1605 \mathrm{cM}^{-1}\right)$, пік при $2900 \mathrm{~cm}^{-1}$, відповідно). Методом електроспіннінгу в лабораторних умовах одержано вуглещеві волокна діаметром 0,8-1,75 мкм.

Ключові слова: кам'яновугільна смола, мезофазна смола, електроспінінг, вуглечеве волокно. 